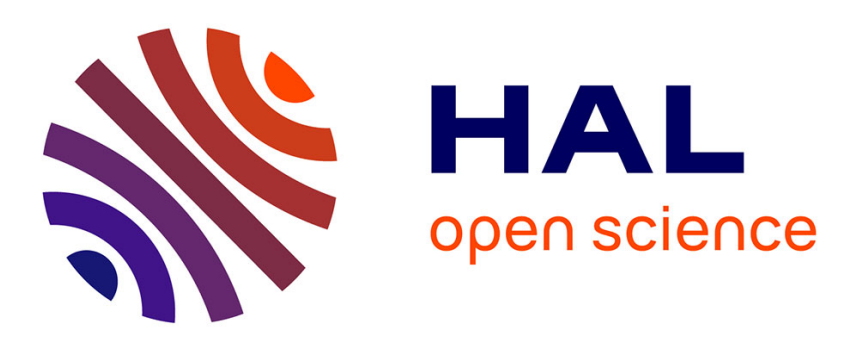

\title{
Metal-free Michael addition initiated multicomponent oxidative cyclodehydration route to polysubstituted pyridines from 1,3-dicarbonyls
}

Frédéric Liéby-Müller, Christophe Allais, Thierry Constantieux, Jean Rodriguez

\section{To cite this version:}

Frédéric Liéby-Müller, Christophe Allais, Thierry Constantieux, Jean Rodriguez. Metal-free Michael addition initiated multicomponent oxidative cyclodehydration route to polysubstituted pyridines from 1,3-dicarbonyls. Chemical Communications, 2008, pp.4207-4209. 10.1039/b805680c . hal-00677037

\section{HAL Id: hal-00677037 https://hal.science/hal-00677037}

Submitted on 7 Mar 2012

HAL is a multi-disciplinary open access archive for the deposit and dissemination of scientific research documents, whether they are published or not. The documents may come from teaching and research institutions in France or abroad, or from public or private research centers.
L'archive ouverte pluridisciplinaire HAL, est destinée au dépôt et à la diffusion de documents scientifiques de niveau recherche, publiés ou non, émanant des établissements d'enseignement et de recherche français ou étrangers, des laboratoires publics ou privés. 


\title{
Metal-free Michael addition initiated multicomponent oxidative cyclodehydration route to polysubstituted pyridines from 1,3-dicarbonyls $\dagger$
}

\author{
Frédéric Liéby-Muller, Christophe Allais, Thierry Constantieux* and \\ Jean Rodriguez*
}

Received (in Cambridge, UK) 3rd April 2008, Accepted 19th May 2008

First published as an Advance Article on the web 10th July 2008

DOI: $10.1039 / \mathbf{b 8 0 5 6 8 0 c}$

A simple metal-free, step-economic and selective access to pyridines from readily available substrates is reported, involving a flexible 4 A molecular sieves promoted Michael addition initiated domino three-component reaction between a 1,3-dicarbonyl, a Michael acceptor and a synthetic equivalent of ammonia.

Pyridines are one of the most important nitrogen heterocycles found in numerous natural and synthetic pharmaceutical agents. ${ }^{1}$ These scaffolds are also of widespread interest in coordination and supramolecular chemistry, as well as for materials science. ${ }^{2}$ The synthesis of these heterocycles has long been an area of intense interest resulting in the development of a wide range of synthetic methods. ${ }^{3}$ Among them, the direct condensation of carbonyl compounds with a source of ammonia is well documented, ${ }^{4}$ but still suffers from some limitations in the substrates, ${ }^{5}$ or involves an oxidative agent ${ }^{6}$ or an elimination step. ${ }^{7}$ Thereby, development of valuable synthetic pathways still remains an industrial as well as an academic challenge. $^{8}$ In this context, the metal-catalysed $[2+2+2]$ cycloisomerisation of alkynes with nitriles largely leads the way nowadays. ${ }^{9}$ However, despite recent spectacular advances ${ }^{10}$ the low availability of some catalysts and substrates associated with the lack of regioselectivity ${ }^{11}$ constitute major drawbacks.

In the course of our studies on the development of new domino $^{12}$ multicomponent reactions (MCRs) ${ }^{13}$ for creation of molecular complexity and diversity ${ }^{14}$ whilst combining economic aspects ${ }^{15}$ with environmental ones, ${ }^{16}$ we recently reported molecular sieves-promoted transformations of various 1,3-dicarbonyls ${ }^{17}$ for the stereoselective synthesis of a series of heterocycles. ${ }^{18}$ In this context, herein we wish to report on a simple metal-free, step-economic and selective access to pyridines from readily available substrates. Thus, we have now designed a flexible domino three-component reaction involving the direct condensation of 1,3-dicarbonyls 1 with Michael acceptors $\mathbf{2}$ and a synthetic equivalent of ammonia $\mathbf{3}$, under heterogeneous catalysis by $4 \AA$ molecular sieves (MS),

Aix-Marseille Université, Institut des Sciences Moléculaires de Marseille, iSm2 CNRS UMR 6263, Centre Saint Jérôme service 531 13397, Marseille Cedex 20, France.

E-mail: jean.rodriguez@univ-cezanne.fr; thierry.constantieux@univcezanne.fr; Fax: + 33-(0)491-288-841; Tel: + 33-(0)491-288-933

$\dagger$ Electronic supplementary information (ESI) available: Complete experimental procedures and characterisations. See DOI: 10.1039/ b805680c

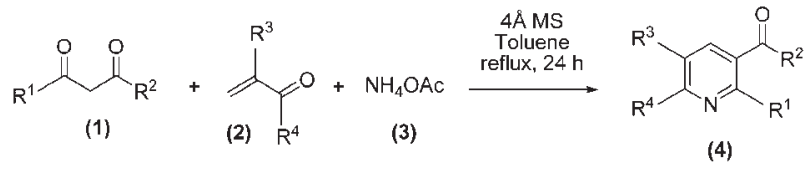

Scheme 1 MCR synthesis of polysubstituted pyridines 4 .

providing after in situ oxidation the corresponding pyridine derivatives 4 in a single operation (Scheme 1). ${ }^{19}$

Due to the nature of the three partners, this strategy may be viewed as a Michael addition initiated biomimetic approach previously formulated by Baldwin and Marazano ${ }^{20}$ for natural 3-alkylpyridinium salts.

Preliminary experiments were conducted with easily available acyclic 1,3-dicarbonyls $\mathbf{1 a - e}$ and Michael acceptors $\mathbf{2 a - c}$. Under optimised conditions, $\mathrm{NH}_{4} \mathrm{OAc}$ proved to be the best source of ammonia $^{21}$ and the corresponding pyridines $\mathbf{4 a - j}$ were obtained by simply heating a toluene solution of the three partners in the presence of $4 \AA \mathrm{MS},{ }^{22}$ acting both as dehydrating agent and as heterogeneous catalyst as shown before. ${ }^{18 a}$ The general applicability is clearly seen from the results reported in Table 1. Acrolein (2a) (entries 1, 4, 8, 10) and methacrolein (2b) (entries 2, 5, 7) may be used, as well as methyl vinyl ketone (2c) (entries 3, 6, 9). Similarly, diversity may be acceded through the use (Fig. 1) of either acetylacetone (1a) (entries 1-3), methyl acetoacetate (1b) (entries 4-6) or ethyl 4,4,4-trifluoroacetoacetate (1c) (entry 7). Interestingly enough, $\beta$-ketoamide $\mathbf{1 d}$ led to the expected pyridines $\mathbf{4 h}$ and $\mathbf{4 i}$ (entries 8 and 9), making this transformation a direct and userfriendly one-pot access to nicotinamide derivatives. Finally, this multicomponent reaction appears as a promising new strategy for the direct metal-free synthesis of bi-aryl

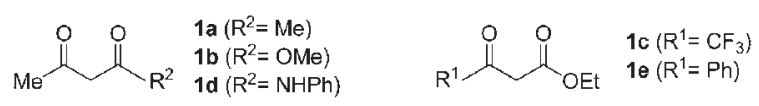

Fig. 1 Acyclic 1,3-dicarbonyl substrates 1 for the MCR.

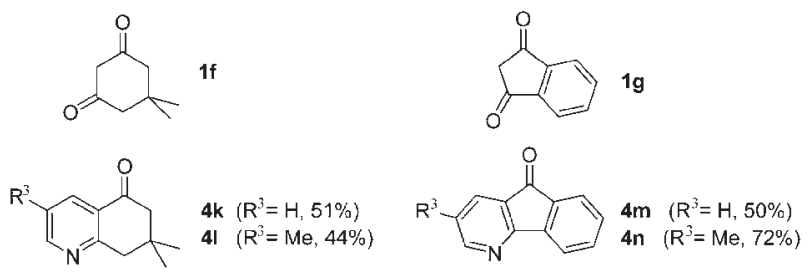

Fig. 2 Bi- and tricyclic pyridines from the MCR. 
Table 1 Pyridine synthesis from acyclic 1,3-dicarbonyls

\begin{tabular}{|c|c|c|c|c|c|}
\hline Entry & Substrate 1 & $\mathrm{R}^{3}$ & $\mathrm{R}^{4}$ & Product & Yield $(\%)^{a}$ \\
\hline 1 & 1a & $\mathrm{H}$ & $\mathrm{H}$ & $4 a$ & 52 \\
\hline 2 & $1 \mathrm{a}$ & $\mathrm{Me}$ & $\mathrm{H}$ & $4 b$ & 65 \\
\hline 3 & 1a & $\mathrm{H}$ & $\mathrm{Me}$ & $4 c$ & 62 \\
\hline 4 & 1b & $\mathrm{H}$ & $\mathrm{H}$ & $4 d$ & 56 \\
\hline 5 & $1 \mathbf{b}$ & $\mathrm{Me}$ & $\mathrm{H}$ & $4 e$ & 44 \\
\hline 6 & $1 \mathrm{~b}$ & $\mathrm{H}$ & $\mathrm{Me}$ & $4 f$ & 65 \\
\hline 7 & 1c & $\mathrm{Me}$ & $\mathrm{H}$ & $4 g$ & 70 \\
\hline 8 & 1d & $\mathrm{H}$ & $\mathrm{H}$ & $4 \mathrm{~h}$ & 61 \\
\hline 9 & 1d & $\mathrm{H}$ & $\mathrm{Me}$ & $4 i$ & 42 \\
\hline 10 & $1 \mathrm{e}$ & $\mathrm{H}$ & $\mathrm{H}$ & $4 \mathbf{j}$ & 65 \\
\hline
\end{tabular}
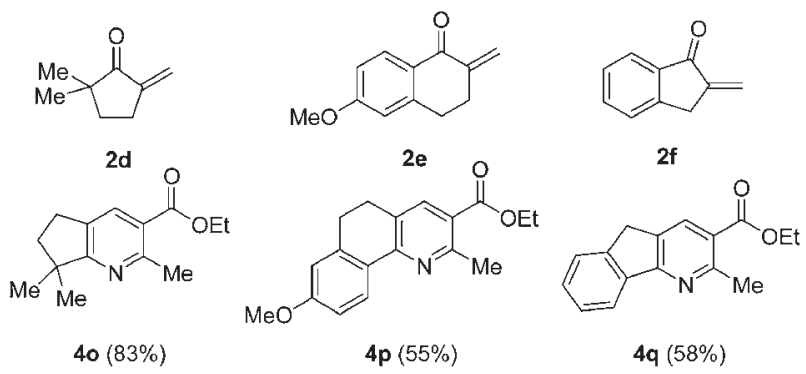

Fig. 3 Pyridines from sensitive Michael acceptors.

compounds from substrates such as 1e (entry 10), opening the way to a flexible design of atropoisomers of bi-aryl ligands. ${ }^{23}$

To further demonstrate the versatility of the method, we then examined the use of cyclic 1,3-dicarbonyls such as dimedone (1f) or indane-1,3-dione (1g) in the sequence, and some representative bi- and tricyclic pyridines are shown in Fig. 2. In all cases, products are obtained with a total regioselectivity. Of particular interest is the one-pot synthesis of 4-azafluorenones $\mathbf{4 m}$ and $\mathbf{4 n}$, which are common skeletons in natural products and molecules of pharmacological interest, ${ }^{24}$ and generally accessed via multistep sequences. ${ }^{25}$

The neutral heterogeneous reaction conditions are also suitable with sensitive Michael acceptors such as $\alpha$-exo-methylene ketones $\mathbf{2 d - f},{ }^{26}$ leading to bi- and tricyclic pyridines $\mathbf{4 o -}-\mathbf{q}$ in acceptable yields (Fig. 3).

From a mechanistic point of view, two multistep sequences have been preliminarily explored. Both evolve through a 1,4-dihydropyridine intermediate 7 which suffers an in situ oxidative aromatisation to the corresponding pyridine. ${ }^{27} \mathrm{We}$ initially postulated that the first step of the sequence may be the molecular sieves promoted Michael addition between substrates $\mathbf{1}$ and acceptors 2 . The corresponding adduct $\mathbf{5}$

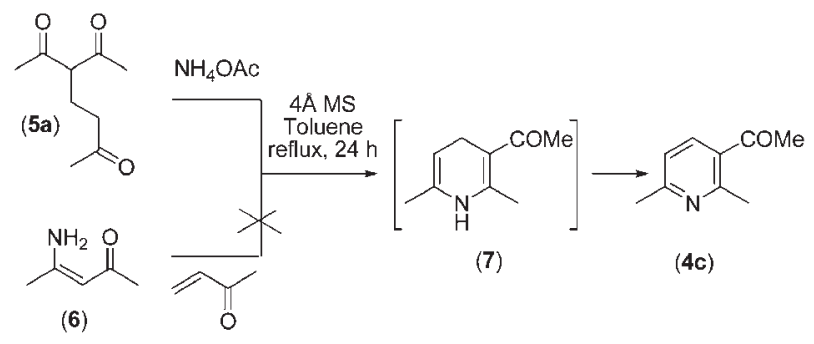

Scheme 2 Mechanistic investigations. may then react with ammonium acetate (3) leading to the dihydropyridine 7 via an intramolecular dehydrative cyclisation sequence. As a validation of this first hypothesis, pyridine $\mathbf{4 c}$ was isolated by mixing the Michael adduct $\mathbf{5 a}^{28}$ with $\mathbf{3}$ under standard conditions (Scheme 2). Alternatively, a more conventional mechanistic pathway could involve the preliminary formation of an enamino ketone intermediate 6, which may lead to the final product via a Hantzsch-type reaction. ${ }^{29}$ Interestingly enough, when 6, independently prepared from $\mathrm{NH}_{4} \mathrm{OAc}$ and acetylacetone (1a), was reacted with methyl vinyl ketone (2c), pyridine $\mathbf{4 c}$ was not formed and starting materials were recovered even after 24 hours (Scheme 2). These preliminary results support our original mechanistic proposal involving a $4 \AA$ MS initiated Michael addition ${ }^{30}$ as the first step of the sequence. ${ }^{31}$

In conclusion, we have developed a regioselective, userfriendly and mechanistically original three-component reaction for the one-pot synthesis of polysubstituted pyridines from readily accessible substrates. The biomimetic like sequence does not require any harmful reagents or metal-based catalysts, and allows construction of highly functionalised heterocycles of both biological and synthetic interest. This pyridine approach should be a good and complementary substrate directed synthetic alternative to other well known methods.

\section{Notes and references}

1 (a) H. J. Roth and A. Kleemann, Drug Synthesis, in Pharmaceutical Chemistry, John Wiley and Sons, New York, 1988, vol. 1; (b) J. P. Michael, Nat. Prod. Rep., 2005, 22, 627-646.

2 M. Balasubramanian and J. G. Keay, Comprehensive Heterocyclic Chemistry II, ed. A. R. Katritzky, C. W. Rees and E. F. V. Scriven, Pergamon, Oxford, 1996, vol. 5, pp. 245-300.

3 D. Spitzner, in Science of Synthesis, ed. D. Black, StC., Georg Thieme Verlag, Stuttgart, 2005, pp. 11-284.

4 (a) A. E. Chichibabin and O. A. Zeide, J. Russ. Phys. Chem., 1906, 37, 1229; (b) F. Bohlmann and D. Rahtz, Chem. Ber., 1957, 90, 2265-2272; (c) H. Nozaki, S. Fujita and T. Mori, Bull. Chem. Soc. Jpn., 1969, 42, 1163.

5 (a) M. C. Bagley, C. Glover and E. A. Merritt, Synlett, 2007, 2459-2482, and references cited therein; (b) A.-L. Blayo, S. Le Meur, D. Grée and R. Grée, Adv. Synth. Catal., 2008, 350, 471-476.

6 See for example: (a) J. S. Yadav, B. V. S. Reddy, A. K. Basak, G. Baishya and A. V. Narsaiah, Synthesis, 2006, 451-454; (b) T. R. K. Reddy, R. Mutter, W. Heal, K. Guo, V. J. Gillet, S. Pratt and B. Chen, J. Med. Chem., 2006, 49, 607-615. 
7 (a) F. Kröhnke, Synthesis, 1976, 1-24; (b) G. J. Reddy, D. Latha, C. Thirupathaiah and K. S. Rao, Tetrahedron Lett., 2005, 46, 301-302; (c) S. Kantevari, M. V. Chary and S. V. N. Vuppalapati, Tetrahedron, 2007, 63, 13024-13031.

8 (a) F. Mongin and G. Queguiner, Tetrahedron, 2001, 57, 4059-4090; (b) G. D. Henry, Tetrahedron, 2004, 60, 6043-6061; (c) A. R. Katritzky, Chem. Rev., 2004, 104, 2125-2126.

9 (a) J. A. Varela and C. Saá, Chem. Rev., 2003, 103, 3787-3802; (b) I. Nakamura and Y. Yamamoto, Chem. Rev., 2004, 104, 2127-2198.

10 For recent examples with various metals, see: (a) Y. Zhou, J. A. Porco, Jr and J. K. Snyder, Org. Lett., 2007, 9, 393-396; (b) H. T. Chang, M. Jeganmohan and C.-H. Cheng, Org. Lett., 2007, 9, 505-508; (c) K. Kase, A. Goswami, K. Ohtaki, E. Tanabe, N. Saino and S. Okamoto, Org. Lett., 2007, 9, 931-934; (d) A. Wada, K. Nogushi, M. Hirano and K. Tanaka, Org. Lett., 2007, 9, 1295-1298.

11 (a) C. Brändli and T. R. Ward, J. Comb. Chem., 2000, 2, 42-47; (b) K. Parthasarathy, M. Jeganmohan and C.-H. Cheng, Org. Lett., 2008, 10, 325-328.

12 (a) Domino Reactions in Organic Synthesis, ed. L. F. Tietze, G. Brasche and K. M. Gericke, Wiley-VCH, Weinheim, 2006; (b) A. Padwa and S. K. Bur, Tetrahedron, 2007, 63, 5341-5378.

13 (a) Multicomponent Reactions, ed. J. Zhu and H. Bienaymé, WileyVCH, Weinheim, 2005; (b) A. Dömling, Chem. Rev., 2006, 106, $17-89$.

14 (a) T. E. Nielsen and S. L. Schreiber, Angew. Chem., Int. Ed., 2008, 47, 48-56; (b) For a recent example of structurally-diversifying domino reaction sequences yielding highly substituted pyridines, see: H. Waldmann, M. Kühn, W. Liu and K. Kumar, Chem. Commun., 2008, 1211-1213.

15 (a) Step-economy: P. A. Wender, G. G. Gamber, R. D. Hubbard, S. M. Pham and L. Zhang, J. Am. Chem. Soc., 2005, 127, 2836-2837; (b) Atom economy: B. M. Trost, Acc. Chem. Res., 2002, 35, 695-705.

16 Special issue in green chemistry: Chem. Rev., 2007, 107, 2167-2820.

17 (a) C. Simon, T. Constantieux and J. Rodriguez, Eur. J. Org. Chem., 2004, 4957-4980; (b) F. Liéby-Muller, C. Simon, T. Constantieux and J. Rodriguez, QSAR Comb. Sci., 2006, 25, 432-438.

18 (a) C. Simon, J. F. Peyronel and J. Rodriguez, Org. Lett., 2001, 3, 2145-2148; (b) F. Liéby-Muller, T. Constantieux and J. Rodriguez, J. Am. Chem. Soc., 2005, 127, 17176-17177; (c) F. Liéby-Muller, T. Constantieux and J. Rodriguez, Synlett, 2007, 1323-1325.

19 For gas phase utilisation of zeolites as heterogeneous catalyst, see: W. Hoelderich and N. Goetz, US Pat., 4960894, 1990.

20 (a) J. E. Baldwin and R. C. Whitehead, Tetrahedron Lett., 1992, 33, 2059-2062; (b) A. Kaiser, X. Billot, A. Gateau-Olesker, C. Marazano and B. C. Das, J. Am. Chem. Soc., 1998, 120, 8026-8034; (c) J.-C. Wypych, T. M. Nguyen, M. Bénéchie and C. Marazano, J. Org. Chem., 2008, 73, 1169-1172.

21 (a) Sulfamic $\mathrm{acid}^{21 b}$ led also to the formation of pyridines, but with lower yields. Hydroxylamine and ammonium chloride were tested without any success; $(b)$ C. Defieber, M. A. Ariger, P. Moriel and E. M. Carreira, Angew. Chem., Int. Ed., 2007, 46, 3139-3143.

22 Crude products were easily obtained with acceptable chemical purity by simple filtration through a short pad of Celite. It is noteworthy that no reaction occurs in the absence of molecular sieves.

23 G. Bringmann, A. J. Price Mortimer, P. A. Keller, M. J. Gresser, J. Garner and M. Breuning, Angew. Chem., Int. Ed., 2005, 44, 5384-5427.

24 K. J. Stauffer, P. D. Williams, H. G. Selnick, P. G. Nantermet, C. L. Newton, C. F. Homnick, M. M. Zrada, S. D. Lewis, B. J. Lucas, J. A. Krueger, B. L. Pietrak, E. A. Lyle, R. Singh, C. Miller-Stein, R. B. White, B. Wong, A. A. Wallace, G. R. Sitko, J. J. Cook, M. A. Holahan, M. Stranieri-Michener, Y. M. Leonard, J. J. Lynch, D. R. McMasters and Y. Yan, J. Med. Chem., 2005, 48, 2282-2293.

25 See for example: (a) A.-S. Rebstock, F. Mongin, F. Trecourt and G. Queguiner, Tetrahedron, 2003, 59, 4973-4977; (b) Multicomponent approach: S. Tu, B. Jiang, H. Jiang, Y. Zhang, R. Jia, J. Zhang, Q. Shao, C. Li, D. Zhou and L. Cao, Tetrahedron, 2007, 63, 5406-5414.

26 (a) J.-L. Gras, Tetrahedron Lett., 1978, 24, 2111-2114; (b) J.-L. Gras, Org. Synth., 1981, 60, 88.

27 The poor stability of dihydropyridines in acetic conditions is well known and has been recently exemplified as a side reaction in the use of Hantzsch ester as a reducing agent: G. Barbe and A. B. Charette, J. Am. Chem. Soc., 2008, 130, 18-19.

28 5a was synthesised from acetylacetone (1a) and methyl vinyl ketone (2c) with a catalytic amount of base-supported P-BEMP: D. Bensa, T. Constantieux and J. Rodriguez, Synthesis, 2004, 923-927.

29 A. Hantzsch, Justus Liebigs Ann. Chem., 1882, 215-236.

30 After optimisation of the reaction conditions, we demonstrated that 2 equiv. of $\mathrm{NH}_{4} \mathrm{OAc}$ (3) were necessary. However, it is noteworthy that when only 1 equiv. of $\mathbf{3}$ was used, the expected pyridine was obtained in admixture with a significant amount of $\mathbf{5}$, which may confirm the preliminary formation of such Michael adduct intermediates in the first step of the sequence.

31 The catalytic properties of $3 \AA$ MS activated with several neutral Lewis bases were also recently reported for the promotion of Michael addition of 1,3-dicarbonyl compounds: R. Villano and A. Scettri, Synthesis, 2005, 757-760. 